\title{
Peningkatan Hasil Belajar Pemecahan Masalah Matematika Melalui Problem Based Learning berbasis Critical Thinking
}

\author{
Aulia Nur Fadilla ${ }^{1}$, Slameto ${ }^{2}$ \\ ${ }^{1,2}$ Program Studi Pendidikan Profesi Guru PGSD Fakultas Ilmu Pendidikan UKSW Salatiga \\ 1952017023@student.uksw.edu \\ slameto@staff.uksw.edu
}

\begin{abstract}
ABSTRAK
Penelitian ini bertujuan untuk mengetahui peningkatan hasil belajar kemampuan pemecahan masalah matematika kelas III SDN Salatiga 1 melalui model Problem Based Learning berbasis Critical Thinking. Penelitian ini termasuk penelitian deskriptif kualitatif dengan variabel tunggal, yaitu hasil belajar kemampuan pemecahan masalah matematika kelas III. Instrumen pengumpulan data menggunakan tes, lembar aktivitas siswa, lembar observasi. Data hasil tes dan pengamatan dianalisis dengan teknik stastistik deskriptif berupa rata-rata hitung dan persentase. Berdasarkan analisis data disimpulkan bahwa tingkat kemampuan pemecahan masalah matematika kelas III tergolong baik. Namun untuk mewujudkan harapan orangtua yang tertuang dalam program sekolah menjadi sekolah unggul, perlu adanya peningkatan hasil belajar. Sekolah dianggap unggul jika telah melampui standar nasional dan di atas dari yang sekolah lain. Untuk mewujudkan hal tersebut, dapat direkomendasikan kepada semua pihak dalam dunia pendidikan agar lebih berupaya dalam meningkatkan proses pembelajaran matematika di sekolah dasar melalui model pembelajaran Problem Based Learning berbasis Critical Thinking. Peningkatan penelitian ini dapat terlihat dari nilai rata-rata 83,64 dengan presentase ketuntasan $82 \%$ pada siklus I menjadi nilai rata-rata 91,07 dengan presentase ketuntasan $90 \%$ pada siklus II. Kesimpulan penelitian ini menunjukkan adanya peningkatan hasil pembelajaran matematika di sekolah dasar melalui model pembelajaran Problem Based Learning berbasis Critical Thinking pada setiap siklus.
\end{abstract}

Kata kunci: aktivitas, hasil, pemecahan masalah, siswa SD, unggul

\section{PENDAHULUAN}

Salah satu mata pelajaran yang diajarkan di sekolah dasar yaitu matematika. Menurut Permendiknas no. 22 tahun 2006, mata pelajaran matematika diajarkan kepada peserta didik bertujuan agar peserta didik memiliki kemampuan sebagai berikut: (1) memahami konsep matematika, menjelaskan keterkaitan antar konsep, dan mengaplikasikan konsep atau algoritma secara luwes, akurat, efisien, dan tepat pada pemecahan masalah; (2) menggunakan penalaran pada pola dan sifat, melakukan manipulasi matematika dalam membuat generalisasi, menyusun bukti atau menjelaskan gagasan dan pernyataan matematika; (3) memecahkan masalah yang meliputi kemampuan memahami masalah, merancang model matematika, menyelesaikan model dan menafsirkan solusi yang diperoleh; (4) mengomunikasikan gagasan dengan simbol, diagram, atau media lain untuk memperjelas keadaan dan masalah; serta (5) memiliki sikap menghargai kegunaan matematika dalam kehidupan yaitu memiliki rasa ingin tahu, perhatian, dan minat dalam mempelajari matematika, serta sikap ulet dan percaya diri dalam pemecahan masalah.

Mengingat pentingnya tujuan matematika bagi peserta didik, diharapkan semua peserta didik dapat menerima dan mengikuti pembelajaran matematika dengan antusias. Sehingga pembelajaran yang telah mereka terima dapat diterapkan dalam kehidupan sehari-hari. Pembelajaran yang demikian akan lebih bermakna dengan melibatkan peserta didik secara langsung dalam suatu pemecahan masalah yang berkaitan dengan matematika. Untuk menarik antusias peserta didik, guru menyediakan beberapa media seperti puzzle yang dapat merangsang kemampuan berpikir kritis peserta didik dalam pemecahan suatu masalah. Hal ini sesuai pendapat Edward dan Knight dalalm Florence Beetlestone, untuk belajar, anak-anak pertama harus terlibat terlebih dahulu, dengan kata lain mereka harus cukup termotivasi untuk memulai dan kemudian melakukan tugas dengan tekun. 
Hudoyo dalam Syamsuddin S (2018) menyatakan bahwa pada hakekatnya matematika itu berkenanan dengan ide-ide, struktur, dan hubungan-hubungannya diatur menurut urutan logis. Ide-ide dalam struktur ini merupakan konsep-konsep yang abstrak yang tersusun secara hirarkis dan penalarannya secara deduktif. Berdasarkan pendapat tersebut, untuk dapat memahami pembelajaran matematika seorang peserta didik harus mampu menguasai materi prasyarat menurut urutan logis. Dalam pembelajaran pemecahan masalah yang berkaitan dengan bangun datar, lebih dahulu seorang peserta didik harus mampu memahami perkalian. Pembelajaran perkalian, diberikan setelah peserta didik menguasai penjumlahan. Begitu pentingnya materi prasyarat yang dijadikan pedoman dalam pembelajaran selanjutnya. Apabila materi prasyarat tidak dikuasai peserta didik, akan berdampak negative pada pembelajaran di kelas selanjutnya. Peserta didik akan merasakan kesulitan menerima materi yang baru. Oleh karena itu, peserta didik harus terlibat aktif dalam setiap pembelajaran. Karena pembelajaran satu mempengaruhi pembelajaran di tingkat selanjutnya.

Berdasarkan hakikat dan sumber-sumber bacaan tersebut, idealnya matematika itu menjadi pembelajaran yang menyenangkan dengan mengenalkan konsep dasar sebagai materi prasyarat, mengembangkan kemampuan berpikir kritis peserta didik dalam setiap pemecahan masalah matematika agar pembelajaran lebih bermakna dan tujuan pembelajaran yang diamanatkan permendiknas tercapai dengan maksimal. Dengan demikian, konsep-konsep yang abstrak dalam matematika dapat lebih dipahami oleh peserta didik. Sesuai dengan tahap perkembangan anak sekolah dasar yang berusia 7 sampai dengan 13 tahun masih berada dalam tahap operasional konkret (Piaget).

Selanjutnya Piaget dalam Florence Beetlestone menyatakan bahwa penekanan pada tindakan dan penyelesaian masalah yang diarahkan oleh diri sendiri mendukung pendekatan dan kegiatan-kegiatan kreatif yang melibatkan pengalaman praktis dan langsung. Pada tahap perkembangan operasional konkret, peserta didik dapat terlibat langsung dalam menemukan konsep pembelajaran. Dalam penelitian ini, menggunakan puzzle untuk menemukan konsep luas dan keliling bangun datar. Sesuai pendapat Enyah Murniati, menggunakan alat peraga dapat memancing imajinasi anak. Pemecahan masalah yang berkaitan dengan bangun datar penting untuk dipahami. Karena materi ini merupakan materi dasar dan terus berlanjut hingga ke tingkatan kelas berikutnya. Sehingga perlu adanya pembelajaran yang bermakna agar peserta didik lebih mendapatkan hasil yang sesuai harapan.

Menurut Martini Jamaris salah satu kesulitan belajar matematika di sekolah dasar yaitu pemahaman bahasa matematika yang kurang. Sebagian siswa mengalami kesulitan dalam membuat hubungan-hubungan yang bermakna matematika. Seperti yang yang terjadi dalam pemecahan masalah hitungan soal dalam bentuk soal cerita. Pemahaman tentang cerita perlu diterjemahkan ke dalam operasi matematika yang bermakna. Masalah ini disebabkan oleh masalah yang berkaitan dengan kemampuan bahasa, seperti kemampuan membaca, menulis, dan berbicara.

SDN Salatiga 01 sudah memberikan pembelajaran tambahan, sebelum pelajaran dimulai. Kegiatan ini bertujuan untuk membiasakan peserta didik lebih siap dalam pembelajaran. Pembelajaran matematika di SDN Salatiga 01 sudah tergolong baik. Namun, untuk mewujudkan harapan orang tua yang tertuang dalam program sekolah, tidak hanya menjadi sekolah biasa, tetapi menjadi sekolah unggul yaitu sekolah yang memiliki kualitas di atas sekolah lain. Untuk mewujudkan harapan tersebut, maka perlu adanya pembaharuan dalam pembelajaran matematika khususnya yang berkaitan dengan pemecahan masalah.

Sebagai sekolah unggulan, SDN Salatiga 01 harus mencapai target di atas rata-rata. Untuk mengatasi hal ini, peneliti menyajikan model Problem Based Learning untuk meningkatkan hasil belajar pemecahan masalah matematika kelas III SDN Salatiga 01. Model Problem Based Learning dipilih karena dalam pembelajarannya melalui masalahmasalah yang dekat dengan kehidupan nyata peserta didik. Dalam pemecahan masalah tersebut, peserta didik mendapat pengalaman secara langsung melalui diskusi kelompok, mengidentifikasi masalah, dan penyelesaian masalah. Beberapa penelitian sebelumnya juga menunjukkan adanya peningkatan hasil belajar dengan diterapkannya model Problem Based Learning pada pemecahan masalah matematika.

Berdasarkan uraian latar belakang di atas, penulis memilih judul "Peningkatan Hasil Belajar Pemecahan Masalah Matematika Kelas III SDN Salatiga 01 Melalui Model Problem Based Learning Berbasis Critical Thinking”. 
Berdasarkan latar belakang di atas, maka dapat diidentifikasi beberapa masalah sebagai berikut: 1) peserta didik cenderung kesulitan menyelesaikan matematika yang berupa soal cerita, 2) peserta didik kurang memahami isi soal dan materi perkalian yang kurang dikuasai, dan 3) jika masalah ini tidak segera diatasi, peserta didik adakan mengalami kesulitan yang berkelanjutan di kelas berikutnya.

Oleh karena itu, peneliti tergerak untuk melakukan penelitian menggunakan model Problem Based Learning dalam pembelajaran pemecahan masalah. Model ini dipilih karena sesuai dengan konsep kebutuhan siswa dan melatih siswa untuk memecahkan masalah bersama dengan kelompoknya. Adapun sintaks model Problem Based Learning yang digunakan dalam penelitian ini merupakan pengembangan dari sintaks yang diuraikan oleh Agus Suprijono dengan tambahan berupa fase Critical Thinking. Sintaks tersebut antara lain: memberikan orientasi tentang permasalahan kepada peserta didik, mengorganisasi peserta didik untuk meneliti, membantu investigasi mandiri dan kelompok, mengembangkan dan mempresentasikan artefak dan exhibit, menganalisis dan mengevaluasi proses mengatasi masalah, serta berfikir kritis dalam menyeleasaikan masalah.

Tujuan penelitian ini untuk meningkatkan hasil belajar peserta didik dan mengembangkan penerapan langkah-langkah model Problem Based Learning berbasis Critical Thinking untuk penyelesaia masalah matematika sekolah dasar.

Dengan demikian, dapat disimpulkan bahwa dengan menerapkan model pembelajaran diharapkan dapat meningkatkan hasil belajar pemecahan masalah matematika melalui model Problem Based Learning berbasis Critical Thinking.

\section{METODE PENELITIAN}

Pendekatan yang digunakan dalam penelitian ini adalah pendekatan deskriptif kualitatif. Pendekatan ini dipilih untuk mendeskripsikan aktivitas belajar peserta didik dan aktivitas mengajar guru dalam melaksanakan tindakan pembelajaran.

Adapun jenis penelitian yang digunakan yaitu Penelitian Tindakan Kelas (PTK) dengan mengacu pendapat Kemmis dan MC.Taggart yang setiap siklus terdiri dari 4 komponen yaitu perencanaan, tindakan, observasi, dan refleksi. Setiap siklus terdiri dari 2 pertemuan, dan pada pertemuan ketiga digunakan untuk melaksanakan tes formatif.

Penelitian ini dilaksanakan di salah satu sekolah dasar Kota Salatiga dengan jumlah 44 peserta didik kelas III yang terdiri dari 16 laki-laki dan 28 perempuan. Pelaksanaan penelitian pada semester II tahun pelajaran 2017/2018.

Adapun teknik pengumpulan data yang digunakan dalam penelitian ini adalah observasi, tes, dan dokumentasi. Observasi dilakukan untuk mengamati aktivitas peserta didik dan guru dalam proses pembelajaran dengan model Problem Based Learning. Tes dilakukan untuk mengukur hasil belajar pemecahan masalah matematika. Tes berisi pertanyaan essay yang akan diberikan kepada peserta didik. Sedangkan dokumentasi digunakan untuk mendokumentasikan proses pembelajaran selama penelitian berlangsung.

Teknik analisis data yang digunakan yaitu analisis statistis deskriptif dengan teknik distribusi frekuensi, grafik/diagram, rata-rata hitung, dan persentase.

\section{HASIL \& PEMBAHASAN}

Hasil penelitian yang dilakukan pada siklus I dan siklus II dikelas III Sekolah Dasar menunjukkan adanya peningkatan hasil belajar dengan menerapkan model pembelajaran Problem Based Learning berbasis Critical Thinking. Hasil belajar peserta didik mengalami peningkatan dari siklus I ke siklus II. Peningkatan tersebut dapat dilihat pada tabel 1 .

Tabel 1 Peningkatan Hasil Belajar Peserta Didik Kelas III

\begin{tabular}{llcccc}
\hline \multirow{2}{*}{ No } & \multirow{2}{*}{ Kategori } & \multicolumn{2}{c}{ Siklus I } & \multicolumn{2}{c}{ Siklus II } \\
\cline { 2 - 6 } & & Jumlah & Persentase (\%) & Jumlah & Persentase (\%) \\
\hline 1 & Siswa tuntas & 36 & 82 & 40 & 90 \\
\hline 2 & Siswa belum tuntas & 8 & 18 & 2 & 5 \\
\hline 3 & Jumlah & 44 & 100 & 42 & \\
\hline 4 & Rata-rata & 84 & - & 91 & - \\
\hline
\end{tabular}


Tabel I menunjukkan perbandingan ketuntasan belajar pemecahan masalah matematika, dapat diketahui bahwa terdapat peningkatan hasil belajar dari siklus I ke siklus II. Pada pelaksanaan siklus I terlihat peningkatan jumlah peserta didik yang tuntas sebanyak 36 peserta didik dengan persentase tuntas $82 \%$, sedangkan 8 peserta didik lainnya masih memperoleh nilai di bawah Kriteria Ketuntasan Minimum (KKM) dengan persentase $18 \%$. Perolehan rata-rata hasil belajar pada siklus I yaitu 84 .

Selanjutnya tindakan dilanjutkan dengan pelaksanaan tindakan siklus II. Hasil pelaksanaan tindakan di siklus II menunjukkan bahwa sebanyak 40 peserta didik memperoleh nilai di atas KKM $>70$ dengan persentase $90 \%$, nilai rata-rata hasil belajar pada siklus II mencapai 91. Dari hasil belajar matematika dan ketuntasan belajar peserta didik siklus II tersebut dapat diketahui bahwa indicator keberhasilan tindakan penelitian telah tercapai.

Berdasarkan data tersebut, hasil belajar pemecahan masalah matematika yang dilihat dari nilai rata-rata dan persentase ketuntasan belajar klasikal dari penerapan model Problem Based Learning berbasis Critical Thinking sudah berhasil. Hal ini sejalan dengan penelitian yang dilakukan oleh Rismaerista Rini (2015), Suci Ariani, Yusuf Hartono, Cecil Hiltrimartin (2017), dan Ni Made Winursiti (2017). Beberapa penelitian tersebut menunjukkan bahwa model Problem Based Learning dapat meningkatkan hasil belajar peserta didik. Sedangkan penelitian yang mendukung dilaksanakannya pembelajaran berpikir kritis yang dilakukan oleh Ifada Novikasari (2009), Ni Kt. Maha Putri Widiantari, I Md. Suarjana, Nym. Kusmariyatni (2015). Penelitan tersebut menunjukkan bahwa pembelajaran berpikir kritis dapat meningkatkan hasil belajar peserta didik.

Keberhasilan tindakan pembelajaran disebabkan oleh kemampuan peserta didik dalam memahami kalimat dalam soal cerita. Untuk menarik antusias peserta didik, guru menyediakan beberapa media seperti puzzle yang dapat merangsang kemampuan berpikir kritis peserta didik dalam pemecahan suatu masalah. Hal ini sesuai pendapat Edward dan Knight dalalm Florence Beetlestone, untuk belajar, anak-anak pertama harus terlibat terlebih dahulu, dengan kata lain mereka harus cukup termotivasi untuk memulai dan kemudian melakukan tugas dengan tekun.
Pada pembelajaran menggunakan model Problem Based Learning ini, peserta didik terlibat aktif sejak awal pembelajaran hingga akhir. Kegiatan dimulai dengan memberikan orientasi permasalahan kepada peserta didik, mengorganisasi peserta didik untuk penyelidikan, melaksanakan investigasi, mengembangkan dan menyajikan hasil, menganalisis dan mengevaluasi proses penyelidikan, dan pada tahap selanjutnya ada berpikir kritis. Modifikasi dalam penelitian ini adalah berfikir kritis. Peserta didik dapat berfikir kritis melalui penyelesaian masalah. Seperti menggunakan puzzle yang menuntut peserta didik untuk berfikir kritis dan menyelesaikan setiap pemecahan masalah yang berkaitan dengan kehidupan sehari-hari.

Jadi, berdasarkan paparan mengenai penerapan model Problem Based Learning berbasis Critical Thinking dapat meningkatkan hasil belajar pemecahan masalah matematika di kelas III. Pelaksanaan pembelajaran dilakukan melalui beberapa tahap yaitu (1) memberikan orientasi permasalahan kepada peserta didik, (2) mengorganisasi peserta didik untuk penyelidikan, (3) melaksanakan investigasi, (4) mengembangkan dan menyajikan hasil, (5) menganalisis dan mengevaluasi proses penyelidikan, dan (6) berfikir kritis. Kemampuan berpikir kritis dapat membantu meningkatkan kemampuan peserta didik dalam menyelesaikan pemecahan masalah yang berkaitan dengan luas dan keliling bangun datar.

Faktor pendukung keberhasilan pelaksanaan dari siklus satu ke siklus dua dikarenakan guru dan peserta didik dapat bekerjasama dalam melaksanakan rancangan pembelajaran dengan baik sesuai dengan langkah-langkah penerapan model Problem Based Learning berbasis Critical Thinking. Kerjasama dan tanggungjawab yang besar dalam semua kegiatan tersebut dapat meningkatkan hasil belajar khususnya dalam menyelesaikan masalah yang berkaitan dengan bangun datar.

KESIMPULAN \& SARAN
Berdasarkan penelitian yang telah
dilaksanakan, dapat disimpulkan bahwa
penerapan model Problem Based Learning
dapat meningkatkah hasil belajar pemecahan
masalah matematika di kelas III Sekolah Dasar.
Peningkatan tersebut ditunjukkan oleh: 1)
persentase ketuntasan peningkatan hasil belajar
peserta didik pada siklus I 82\% menjadi $90 \%$


di siklus II sehingga terjadi peningkatan sebesar $8 \%$.

Berdasarkan simpulan di atas, maka diajukan saran sebagai berikut:

1. Kepala sekolah hendaknya selalu memberikan pembinaan dan pengawasan mengenai peningkatan kompetensi guru dalam menerapkan model-model pembelajaran, salah satunya model Problem Based Learning agar pembelajaran peserta didik bisa lebih bermakna.

2. Guru, hendaknya selalu memfasilitasi peserta didik agar ikut terlibat aktif dalam pembelajaran secara langsung sehingga pengalaman peserta didik terbentuk dan mudah dalam menyelesaikan pemecahan masalah.

3. Bagi peneliti, hendaknya hasil penelitian ini dapat dijadikan pedoman jika akan melakukan penelitian yang sejenis, dengan memperbaiki kelemahan-kelamahan di penelitian mendatang.

\section{DAFTAR PUSTAKA}

Astuti, Dwi Afnan Puji. 2018. Pengaruh Model Pembelajaran Problem Based Learning Terhadap Kemampuan Pemecahan Masalah Matematika Siswa Sekolah Dasar. Jurnal Sekolah (JS), Vol 2 (2), 102-109.

Beetlestone. 2012. Creative Learning: Strategi Pembelajaran untuk Melesatkan Kreatifitas Siswa. Bandung: Nusa Media.

Dahar, Ratna Wilis. 2011. Teori-Teori Belajar dan Pembelajaran. Jakarta: Erlangga.

Dipl, Hosnan. 2014. Pendekatan Saintifik dan Kontekstual dalam Pembelajaran Abad 21. Bogor: Ghalia Indonesia.

Farimah, Wike. Peningkatan Hasil Belajar dan Keterampilan Pemecahan Masalah Matematika Melalui Model Problem Based Learning Berbantuan Kotak Hitam Putih. Kalam Cendekia, Vol 6 (2.1), 7-12.

Heruman. 2010. Model Pembelajaran Matematika di Sekolah Dasar. Bandung: Remaja Rosdakarya.

Jamaris, Martini. 2015. Kesulitan Belajar: Perspektif, Asesmen, dan Penanggulangannya Bagi Anak Usia Dini dan Usia Sekolah. Bogor: Ghalia Indonesia.

Murniati, Endyah. 2012. Mengajarkan Matematika dengan Fun. Yogyakarta: Mentari Pustaka.

Pagarra, Hamzah. 2016. Peningkatan Hasil Belajar Matematika Melalui Model
Pembelajaran Problem Solving pada Siswa Kelas V SDN Kakatua Kecamatan Marisokota Makasar. Jurnal Publikasi Pendidikan, Vol VI (3), 203-213.

Rifai, Achmad dan Anni, Catharina Tri. 2009. Psikologi Pendidikan. Semarang: Universitas Negeri Semarang Press.

Rusman. 2012. Model-Model Pembelajaran Mengembangkan Profesionalisme Guru. Jakarta: RajaGrafindo Persada.

Slameto. 2010. Belajar dan Faktor-faktor yang Mempengaruhinya. Jakarta: Rineka Cipta.

Sudjana. Nana. 2012. Penilaian Hasil Proses Belajar Mengajar. Bandung: Remaja Rosdakarya.

Surya, Yenni Fitra. 2017. Penerapan Pendekatan Problem Solving untuk Meningkatkan Hasil Belajar Siswa pada Pembelajaran IPA Kelas IV SDN 002 Langgini Kabupaten Kampar. Jurnal Publikasi Pendidikan, Vol 7 (3), 119-126.

Syamsuddin. 2018. Analisis Kemampuan Berhitung Siswa Kelas III SD Negeri Kecamatan Ulaweng Kabupaten Bone. Jurnal Publikasi Pendidikan, Vol 8 (1), 71-75.

Tampubolon, Saur M. 2014. Penelitian Tindakan Kelas Untuk Pengembangan Profesi Pendidik dan Keilmuan. Jakarta: Erlangga. 